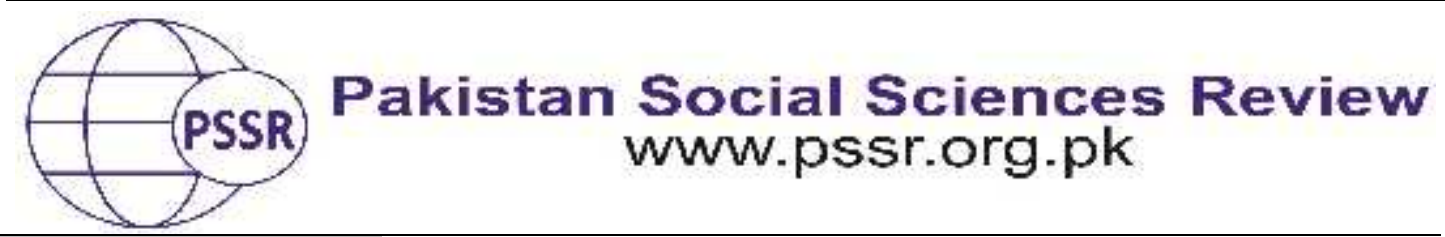

RESEARCH PAPER

\title{
Women can be Destroyed but Not Defeated: Undefeatable Struggle of Sisters in Toni Morrison's Paradise
}

Muhammad Babar Jamil ${ }^{1}$ Muhammad Akbar Khan ${ }^{2}$ Dr. Shabbir Ahmad ${ }^{3}$

1. Assistant Professor, Department of English, GIFT University, Gujranwala, Punjab, Pakistan

2. Associate Professor, Department of English, The University of Lahore, Gujrat Campus, Punjab, Pakistan

3. Assistant Professor, Department of English, University of Sahiwal, Punjab, Pakistan

\section{PAPER INFO}

Received:

March 21, 2021

Accepted:

July 01, 2021

Online:

July 20, 2021

Keywords:

African Feminism,

Alienation,

Female Friendship,

Patriarchy,

Struggling Women

*Corresponding

Author

babarjamil@gift.

edu.pk

\section{ABSTRACT}

This article discusses the theme of female friendship as a possible way out of alienation (spiritual or physical detachment in a relation) in gender relations, and then goes on to argue that this female friendship itself suffers from alienation in the long run. While foregrounding the healing power of female bonding which may allow women to survive under patriarchal exploitations, this article brings fore a fact that this bonding nevertheless may be corrupted by the power of patriarchy and lead women finally to where they start, namely, alienation. The common experience of the black women urges them to form bonds to satisfy their mother hunger, deal with their problematic past, and fight against the discrimination on the basis of race, class and gender. Female friendship assists women in counterbalancing the effects of patriarchy and gives them a sense of independence. However, Morrison's 1998 novel Paradise, by portraying alienated relationships, emphasizes the omnipresent power of patriarchy and warns women of the dangers that the female bonding is exposed with. It brings to light Morrison's concern with African Feminism as she brings fore the issues that women have to deal with in their struggle to gain freedom from discriminatory patriarchal restrictions that create hindrance to women living a life of their own choice.

\section{Introduction}

Female bonding is a very significant process in the considerations of many theorists such as Clenora Hudson-Weems, bell hooks, and Obioma Nnameka,. Elizabeth Abel, for instance, reflects on women's friendship as a theory " to give form, expression, and reality to the ways in which women have been for our Selves and each other (Abel,1981,p. 434)". Female friendship, first and foremost, is a non- 
sexual relationship by nature based on caring and sharing with each other. It tends to be a public relation formed among mature females. Weems defines it an"asexual relationship ... Enjoying, understanding, and supporting each other (Weems, 2004, p $65)^{\prime \prime}$. Women friends provide moral support and care for each other beyond the concern for self or family; hence it is an effort to help and elevate each other. And "Works by black women writers also show that there are other channels, such as writing and sisterhood (Nnaemeka,1997,p.19)". It is a powerful tool against patriarchal forces as mentioned about women's group struggle in "Veiled Courage: Inside the Women's Resistance against Violence Through Their Writings" (Imran et al., 2020).Thus, ObiomaNnaemekacorrelates this women friendship with the black women writers who have used this mutual bonding as a theme in their works for raising a combined voice against various pressures and challenges faced by black women

Morrison presents such a relationship in many of her novels such as Sula,Love, and Paradise where the women characters build connections of various kinds among themselves. In Sula, Nel and Sula form a bonding that makes them to develop themselves; in the same way, in Love, Christine and Heed form a friendship to fill in blank spaces in their lives, and Convent women cultivate friendship in Paradise to resist black patriarchal oppression. However, such sisterhood tends to dissipate and gives way to new tensions and conflicts in Morrison s novels. The female friendship in Morrison therefore involves two phases. First, female friendship starts and develops in response to outside pressures, and then this friendship suffers setbacks. Morrison clearly highlights the harmony that embodies the first phase of friendships and the difficulties that make the second phase of friendship fail. First phase of friendships is more successful in Morrison s fiction than the second phase because the second phase of this friendship concerns the problems that turn the first phase into fruitless efforts. Critically speaking the second phase is more important as it brings into focus very important factors of patriarchy and class exploitation. This second phase is as significant as the first; however, it calls for more explication as it presents a gloomy picture for the future of women fighting for their own deliverance from the alienation caused by the patriarchal tradition, though not without confidence in women if they persist with tenacity and intensity.In fact, Morrison intends to seek through her writing the survival of women as subjects, not as object, and freedom for women from patriarchal oppression thus working as an African feminist writer.

Dubek connects the presentation of the theme of female friendship in fiction with the African feminism:" in defining an African feminist literary tradition, critics highlight female friendship and women's solidarity" (Dubek, 2001,p. 212). And Morrison's texts reflect the lives of the black women in America, particularly the female friendship in black women.She brings fore the complexities of women relationships. Through a careful combination of characterization, settings and contexts, and plot development, her works examine black female friendship and the challenges it faces. The black women have been suffering from racial discrimination, 
but this race issue is related to class issue since most black women are from the lower class, unfairly treated and appropriated in a patriarchal structure which oppresses women. She presents all issues related to female friendship and social complexities by going into psychological depths of the women characters. Through a mixture of characterization, setting, and plot development her works examine black female friendship and the challenges it faces. The black women have been suffering from racial discrimination but more than that this problem is their belonging to lower class, unfairly treated and appropriated in a patriarchal structure which oppresses women.

Throughout their transaction, female bonding finds it most indispensable for black women since gender issue suffers from the negative impact of the first two things, race and class. The peculiarity of Morrison is that she goes on to tell her black readers that this female bonding may not work. For example in her eighth novel, Paradise,Morrison critiques the destructive and overwhelming influence of patriarchy on women by drawing on the fact that alienation arises when social and moral pressures make individuals feel as objects with no will of their own. In itMorrison describes how her female characters undergo a struggle to become selfaware and somewhat in control over their world by forming groups following Virginia Woolf's concept of "A Room of One's Own." Morrison then goes on to make her readers ask: do they succeed in coming out of their alienation as a result of such isolated grouping, bonding and friendship?

\section{Discussion}

From the time man found that his/her life has a sociopolitical aspect, especially after the Industrial Revolution, individuals or groups have experienced alienation, a situation in which one person or a group is in substantial disagreement with the rest of society (Sinari, 1970, p. 123-130). It is what we see in Toni Morrison's eighth novel, Paradise, which exploresthe relation between gender identity and alienationwhile critiquing the destructive yet overwhelming influence of patriarchy.Set in 1976, the story is about two societies - the town of Ruby, an isolated small city in Oklahoma, and a small independent group of women who are living in Convent, situated on the borders of Ruby. In Convent, women help each other and struggle to make a home free from fierceness and biasedness. The ways of life of Ruby and Convent are in conflict each other because of which a big clash occurs whichstarts with the contention of Ruby's men to "kill the white girl first" (Morrison, 1998, p.3). The white girl, the only white girl who is murdered by the group of men, is not revealed in the novel. Thus, Paradise is a novel of women massacre by a patriarchal system working its way into the daily lives of women in black communities in America some decades before. In fact, the black menactually imitated the white system of domination to rule over the black women. However, this articledraws ourattention to the ways the black women struggle to revert the evil circumference of their lives, with a focus on the moments of their consciousness that help them to resist at times whenracial and gender discriminations pushthemto experience a state of alienation, both psychological and physical. 
During the last few decades, black people have been confronting the upheavals and ordeals of racial alienation. Racial alienation or estrangement is resulted by the omnipresent discrimination due to skin color difference among whites, dark skinned and light skinned African Americans. This study selects theoretical framework of an emerging characteristic of modern literature: alienation, a concept of the feeling of to be detached from others and even detached from one's self because of inter and intra- racial racism as portrayed in African American literary works such as the narratives of a black female writer Toni Morrison. The object of this study work is to examine the alienated characters who are representatives of the victimization and maltreatment because of color by whites and their own black males. The major study focus revolve around the ordeals of inter and intraracial discrimination in Morrison's fictional world. This study work empowers the view that racially alienated black community is a significant part of American literary genres because the black people have gained crucial place in American literature. Toni Morrison, a renowned female African- American writer who has won the Noble Prize in 1993, wrote her fictions as an embodiment of the representation and expression of the ordeals, sufferings and pains of black community not only at the hands of white but by their own people too. Her literary works are the expressions of the complications of marginalized black community. One of the important issues of Toni Morrison's novels is social and psychological alienation of black women in their own black society that makes her the true representative of black community. This study investigates the self alienated characters of Morrison's novels, their psychological sufferings in the search of their own selves and the most painful conundrum of being exiled by their own black community.

This study deals with the concept and application of intra- racial prejudice among blacks how they are oppressed by the people of their own community. In this study, the major emphasis is not upon the differences outside rather on the devastation of differences within the same black peoples. The victimized become victimizers when they feel that they have slight superior position among others. Further this study is about "alienation" which is the very result of racial and color differences among colored people of same community in Morrison's Paradise. The study deals with the impacts of isolation, the search of one's own self, the traumas of being marginalized and psychological devastation of blacks in their own society by other blacks, here, the black females. Most researchers talk about the differences between two quite different races: whites and blacks in Toni Morrison's narratives but this study is about the differences within blacks. It means blacks try to suppress other blacks just because one group has more power as compared to other black skinned people. A boundary line between two entirely different aspects is easily understandable but to find out the differences between two similar aspects may be challenging. Most researchers talk about the effects of oppression imposed by superiors but this study highlights and the concept of being strange and alien among the folks of same race. 
It is relevant here to refer to Morrison's master thesis when it comes to the discussion of the black females in Paradise: "In the world that Mrs. Woolf posits, good is freedom of will and evil is the imposition of will" (Morrison, 1955, p.13). This interpretation of Morrison of Woolf's characters may well apply to her own novel Paradise. Here the black women form an isolated community in order to have a life of their own, but the black men do not allow them to have "rooms of their own." The men attack the secluded women community in the name of religion, and it corresponds with Morrison's view about Woolf's attitudes towards religion in her novels:

When she does speak fondly of religion it is invariably in reference to convents and nuns. That part of religion appears to her inoffensive, as it suggests alienation from the world rather than dominion over it (Morrison, 1955, p.13).

In Paradise Morrison introduces a community of secluded women who represent liberal feminist sort of ideas and who struggle for free and independent life. Morrison's female characters here pursue to embody themselves as powerful subjects. Speaking with more clarity, black female subjects make an effort to demonstrate their subjective positions including their color and body in a sociogeographically hostile environment. This fight for freedom is very clear and visible here, as during this struggle they appear to be taking control over their world. However, the point is: Do they succeed in coming out of this marginalization and alienation?

In an interview, Morrison talks about the need for African American women to save guard the male by providing them such places in which they can put into practice their "male rites, whether it's drunkenness, arrogance, violence" (Danille, 1994, p. 113-114). Morrison responds further to the other questions asked by the speaker:

So women have the domestic burden of trying to keep things going, on the one hand, and, also protecting the male ..... It is a certain kind of fraudulent freedom and destructive perhaps (Danille, 1994, p. 113-114).

Morrison's critical standpoint for African American males is very much evident in Paradise. Here the dangerous patriarchs are free from any answerability for their deeds of aggression as absolute rulers of an all-black town. It correlated with the finding: "Morrison brings to the fore various challenges faced by female bonding and warns women against the dangerous power of patriarchal structures"(Ahmad,et.al.,2020,p.327). In Paradise, Morrison reprimands a violent manhood that depends on the stigmatization of women as others and devilish. And if the very foundation of Morrison's fiction is race, then this race often goes along with gender as Morrison is concerned, consciously or unconsciously, with the cultural effects of racialized and gendered thinking.

The present analysis of Paradise is based on the fact that alienation arises when social and moral pressures make individuals feel as objects with no will of 
their own. It associates this feeling of objectification with the subject-object dichotomy in terms of alienation. A feeling of objectification is created when someone finds him/herself under the control of another person. This someone will undergo a struggle for self-realization and personal freedom, when denied such a struggle, the individual will move on a path of endless alienation. Morrison's text focuses on African American women characters who desire for moving beyond inferior subject positions to new agentive subject positions with powers of agency. The Convent makes possible the existence of a space that not only brings surety of a temporary survival there -to a level where they can build subject positions other than that of suppression and defeat.

Paradise presents two types of black communities. A small community of isolated women gathered in Convent and Ruby is the community founded on patriarchal supremacy. Ruby s patriarchs adopt a coercive mechanism to suppress women and deprive them from any active life with independence. In contrast, the Convent women adopt a more fluid idea of identity formation that enables individuals to survive and develop. Each woman at the Convent possesses an individualistic self and an active subject position as all of them have come there by escaping due to different reasons created by the powerful patriarchal culture. Although most of the women are African-American, one is white and one is of mixed race. The novel offers an isolated community that accepts racial diversity. The failing Mother Mary Magna is cared by Consolata Sosa who breaks into desolation after her death. Lone Dupres, an olden herbalist who is lifted as a baby, clarifies to Consolata how to nurture the dead. Both Dupres and Consolata save Deacon Morgan s son from a drunken car smash. After this incident, the outsiders begin to come back to Convent: the four rebellious women, Mavis, Gigi, Seneca and Pallas, all in a changed condition of severe misery. These four women make Convent, and Consolata leads them. From time to time the solitary women from Ruby walk or drive along the flat straight road to the Convent where they find medical facilities, shelter and protection. All require a respite from the judgmental and imposing life in Ruby. It can be said, then, that these solitary women are the descendants of a long line of Morrison s outsiders from Sula, who wants to make herself rather than making babies, through wise Pilate in Song of Solomon and ghostly beloved to the mysterious Wild who hovers at the edges of Joe Trace s past in Jazz. Paradise completes the cycle with explorations of death of isolated and marginalized black women. One factor behind the killing of these women is religion which reminds the reader once again of Morrison's master's thesis where she analyses Woolf's linking of imposition of will, and concept of right and wrong with religion, "In the world that Mrs. Woolf posits, good is freedom of will and evil is the imposition of will. She remains unimpressed by the definitions of good and evil given by various religions, and finds religion itself guilty of imposition" (Morrison,1998, p. 13). In fact Men of Ruby attack on Convent women because in their interpretation of religious teachings women are wrong and they are right. 
The men of Ruby have re-created Eden that suits their own specific reasons and viewpoints. At a distance of seventeen miles from Ruby, another "Paradise" has been created. This land Convent is inhabited by women who have fled from oppression and depression -- a place that Ruby s men see as "dark and malevolently disconnected from God s earth" (Morrison,1998,p.18). Consolata s declaration of these women as "broken girls, frightened girls," is a valid description (ibid, 22). Contrasted with Ruby s residents, these women appear more vibrant, though in fact they are refugees from life. As the men of Ruby attack on the unarmed women, Morrison makes it very much clear that the hazards of both narrow mindedness and a belief in one's own goodness are very much disastrous. The portrayal of the women at the last pages of the initial chapter brings forth the irony in the deed of men: "God at their side, the men take aim. For Ruby" (Morrison,1998,p.18). From the male point of view, the women, like Eve, portray a loss of innocence and removal from Eden, a damage the men wish to prevent. But as smeared with "holy oil," the women are also Christ-like sacrificial figures. The text of Paradise, then, serves as space of struggle for survival. The important point to be noticed is that,after getting independence from the patriarchs of Ruby, Morrison does not present the Convent to survive as an earthly paradise for black women. She finally shakes the minds of her readers by an ending of the novel which implies that the path of struggle for women is neither completed nor closed, but a state that needs to be incessantly worked on and struggled for.

Morrison tries to show the way racism sometimes works itself into gender. United in face of denunciation by whites and by light-skinned blacks, the men of Ruby do whatever they could do to disturb any women who have shown signs of "racial tampering" (ibid,196-97). Ruby s official story about Billie Delia provides the clearest illustration of this process. Delia s grandfather, Roger Best, first breaks the blood rule by marrying a woman who "looked like a cracker" (ibid, 196), whom Steward considers "the dung we leaving behind" (p.201); Ever since, Roger and his descendants have spent their days "trying to please, to make up for" (p. 201). Roger s daughter, Pat -- born before her parents are married -- has worked so hard to attain a sense of dignity that she comes to view her own light-skinned daughter, Billie Delia, as a liability. Within the gendered racial economy of Ruby, Billie Delia gets permanently branded as the town tramp for pulling down her panties in public at the age of three, even though she remains a virgin throughout the novel. Even her own mother can no longer separate what she sees from what she fears seeing in Billie Delia s behavior. As Pat Best ultimately realizes, she has participated in the community's gendered sacrifice of her racially unacceptable daughter. By so carefully and forcefully highlighting Ruby's criminalization of particular women, Paradise gives a compelling narrative form to the historical fact that has a link bydeclaring, "women who refuse to embrace the nuclear family as a paradigm," as their illegal acts. What becomes very much clearfrom the text is that for Ruby's patriarchs defense is synonymous with aggression.

The town of Ruby is a site with marginalized atmosphere for the exertion of fierceness on women. As the women are excluded, the city becomes profoundly 
polarized, with "they," the first word of the novel, immediately recognized as a male pronoun. The novel tells the reader that these "armed" men are searching rooms "obliged to stampede or kill" (Morrison,1998,p.3-4), because "when they return from World War II, Haven's men find the town failing financially and, in their eyes, morally" (Beauleau,2003,p.261). In other words, the Ruby men feel that as moral corruption comes from the women, they have the obligation to purge the city of female presence. Morrison makes references to God and the Bible by claiming that the black females in Convent are in denial of the Biblical teachings. Since the women of the Convent or "the bodacious black Eves" refuse to surrender and to be submissive wives, the Ruby men decide to kill them and believe that God is "on their side" in this endeavor. Morrison's reference to the Bible is intentional, since the word "patriarch" may be traced back to its Biblical allusions.

One of the very much disturbing aspects of the novel, according to Widdow son, is the question of how could some men as a group "gun down in cold blood a group of defenseless damaged women because they were women?" (Widdowson,2001,p. 316). The men of Ruby feel exultation in confronting death and instigating it because they believe that the women are devilish sinners and they feel justified in their "cold blooded" actions. These "throw-away" women have been "swept out the door" (silenced or dead) for years, even before the men invade the Convent. If they are indeed dead, no one seems to be searching for them, no one misses them, no one is aware of their absence. Indeed, the conclusion of Beloved applies to the women in Paradise: "Disremembered and unaccounted for, she cannot be lost because no one is looking for her... Although, she has claimed, she is not claimed" (Morrison, 1987, p.321). In addition, like Beloved who leaves foot-prints that gradually disappear; these women apparently leave no footprints.

But the men of Ruby now have problems with these silenced women, because they are coming back to speak out ("blow back into the room"). Here, the isolated women are being attacked and destroyed by the men of Ruby. Like the mythical birds of Philomela and Procne, the disappeared dead bodies of women in this novel do suggest a struggle against patriarchy. The flight of the two sisters is a flight away from power and silence. Their inaudible song becomes an utterance of protest against gender injustice and inequality. Jane Marcus discusses Philomela s situation, "the voice of the nightingale, the voice of the shuttle weaving its story of oppression, is the voice which cries for freedom" (Marcus,1984,p.79). The political confrontation becoming apparent here is a collective voice of isolated and marginalized black women who are bound to have solo flight against patriarchy to have an untrammeled and prosperous life.

The women of the Convent stay together by creating an open house to challenge the social and historical structures that surround them. While the black men do not want to grant them independence, the disappearance of the murdered bodies positions the convent women, or rather the idea of the bodies as indestructible inspires them. The Convent emerges as a space where cultural 
hybridity becomes possible with surety: "the women are associated with movement, liberty, and sharing" (Krumholz, 2002,p. 25). The men of Ruby look at hybridity as an evil and they decide to destroy difference by attacking the women. The women in the Convent, however, take hybridity as possessing a reforming power. As they discard the imposed identities and exchange their understandings with each other, the Convent is established as a place of harmony which allows for cultural difference.

Paradise is an expressive narrative which stresses how prejudice gives rise to narrowness. The clusters of women who try to discover themselves at the Convent have one goal in common: to search for freedom from the "narrowness" of the prevailing male tradition. The Oven, where young people sit together for gossip, may serve as a symbol of such struggle. It is "round as a head, deep as desire," with significant words on the "Oven s iron lip" and "at the base of the Oven s mouth" (Morrison,1998,p.6-7).These words bring fore the conflict between the fathers and the children. Steward's desire for purity of race and sexuality, in the name of religion, leads to the reproaching of the women and the construction of the idea that the other, as the impure, needs to be destroyed. It is similar to what has happened to Sula in Sula and Jadine in Tar Baby. Sula dies as an alien to her community that does not allow her to have the long desired liberty. Similarly Jadine has to flee to Paris to find success in her professional career which is denied by the norms of the communal tradition represented by her lover Son and her adopted mother. In fact Morrison develops awareness about the black woman's subjectivity and dignity in American society. Like Morrison s earlier females, Sula or Hagar for instance, various females in Paradise struggle against the one sided rules of patriarchy, such as Mavis, Gigi, Seneca, Pallas and even Billie Delia, who as outsiders in Ruby fight to get rid of their marginalization and resultant alienation.In this sense this work finds an association with other similar works on the issue of family need as:Parental Hunger and Alienation in Toni Morrison's The Bluest Eye(Ahmad, et. al., 2020) where the writers have analyzed the need of mutual bindings in order to combat various challenges of life, especially in the lives of the people considered to be on the margin of the society like the black females in American history.

Critics tend to foreground the aesthetic side of Morrison's novels over their ideological underpinnings such as Richard L. Schur asserts "political undercurrents of her work" (Schur,2004, p 278). There is no denying that Morrison is known for her style and artistry which is peculiarto African American literature.However, there is also no denying that her novels in general and Paradise in particular demand for greater freedom for black women who are forced to live under patriarchal oppression. In other words, Morrison's works have depth of analysis and strength of expression when it comes to the understanding of African American women, "care offered by Paradise comes closer to Alison Jaggar's notion of a feminist rather than feminine" (Michael,2002,p. 643). The same type of description is given in the last chapters of Tar Baby where Morrison uses soldier ants to refer to the flight of Jadine to Paris. "But soldier ants do not have time for dreaming" (Morrison, 1981,p. 292). The emphasis is on "no time for dreaming" which imparts a sense urgency and 
immediacy which is rare in other African American female writers. Thus, this book brings fore some other similar works as "Redefining Americanism and American Literary Tradition: Hospitality, Ethics and A Transcendent Humanism in Cormac McCarthy's Fiction (Ahmad, et. al. 2020)" where the writers have emphasized on creating and redefining a new American Literary Tradition based on mutual understanding and harmony rather than battling with each other.

\section{Conclusion}

In Tar Baby it is the male ant that is sacrificed while the female ant survives asJadine flies to Paris and survives adopting an estranged position from her lover Son. In Paradise, however, the women are sacrificed when they feel estranged from the males of Ruby and establish an isolated Convent. This is one of Morrison's successful techniques for dealing with her central themes, as observed by Richard L. Schur: "Morrison offers the same stories from multiple and contrasting views" (Schur,2004,p. 276). It implies that the stories of Tar Baby and Paradise, among the rest of Morrison's novels, are similar in that Jadine flies to Paris while the women in Paradise fly to heaven after the murder. It signifies that to end such flights of black women in alienation of gender relation, "decolonization of masculine" is necessary and unless it happens the females will undergo isolation and alienation in their gender relation with the patriarchs. 


\section{References}

Abel, E. (1981). (E)Merging Identities: The Dynamics of Female Friendships in Contemporary Fiction by Women. Signs: Journal of Women in Culture and Society, 6: 413-35.

Ahmad, S., Chaudhary, F., \& Murtaza, G. (2020). Parental Hunger and Alienation in Toni Morrison's The Bluest Eye. International Review of Literary Studies, 2(1), 22-31.

Ahmad, S., Mahmood, M. I., \& Abbas, S. (2020). A Study of Alienation in Toni Morrison's Sula: Passive Patriarchy, Marriage and Female Friendship. Research Journal of Social Sciences and Economics Review, 1(4), 322-328.

Ahmad, S., \& Mahmood, M. I. (2020). Redefining Americanism and American Literary Tradition: Hospitality, Ethics and A Transcendent Humanism in Cormac McCarthy's Fiction. Pakistan Social Sciences Review, 4, 849-861.

Morrison, T. and Danille Kathleen Taylor-Guthrie. 1994. Conversations with Toni Morrison. Jackson: University Press of Mississip, p.113-114

Dubek, L. (2001). Lessons in Solidarity: BuchiEmecheta and Mariama Bâ on Female Victim (izer)s. Women's Studies, 30 ,p. 199-224.

Weems, C. (2004). Africana Womanist Literary Theory: A sequel to Africana Womanism: Reclaiming Ourselves. Trenton: Africa World Press.

Imran, M., Chen, Y., Wei, X. M., \& Akhtar, S. (2020). Veiled courage: Inside the women's resistance against violence through their writings. Asian Journal of Women's Studies, 26(1), 74-93.

Krumholz, L. J.(2002). Reading and Insight in Toni Morrison's Paradise. African American Review ,36(1), pp.21-23

Marcus, J.(1984). Still Practice, A/Wrested Alphabet: Toward a Feminist Aesthetic. Tulsa Studies in Women's Literature, 3(1), pp. 79-97

Michael, M. C.(2002). Re-Imagining Agency: Toni Morrison's Paradise. African American Review, 36(4), pp. 643-661

Morrison, T.(1977). New York: Alfred A. Knopf.

.... (1987). Beloved. New York: Alfred A. Knopf.

.... (1998). Paradise. New York: Alfred A. Knopf.

.... (1981). Tar Bbay. New York: Alfred A. Knopf. 
Morrison, T.(1955). “Virginia Woolf's and William Faulkner's Treatment of the Alienated." Diss. CornellUniversity,pp.13

Nnaemeka, O. (1997). Introduction: Imag(in)ing Knowledge, Power, and Subversion in the Margins. The Politics of (M)othering: Womanhood, Identity, and Resistance in African Literature. Ed. ObiomaNnaemeka. London: Routledge, 1-26.

Schur, R. (2004). Locating "Paradise" in the Post-Civil Rights Era: Toni Morrison and Critical Race Theory. Contemporary Literature, 45(2), pp. 276-299.

Sinari, R. (1970). The Problem of Human Alienation. Philosophy and Phenomenological Research, 31(1), 123-130.

Widdowson, P. (2001). "The American Dream Refashioned: History, Politics and Gender in Toni Morrison's Paradise." Journal of American Studies 35.2, Part 2: Warring in America: Encounters of Gender and Race (Aug., 2001):313-335 